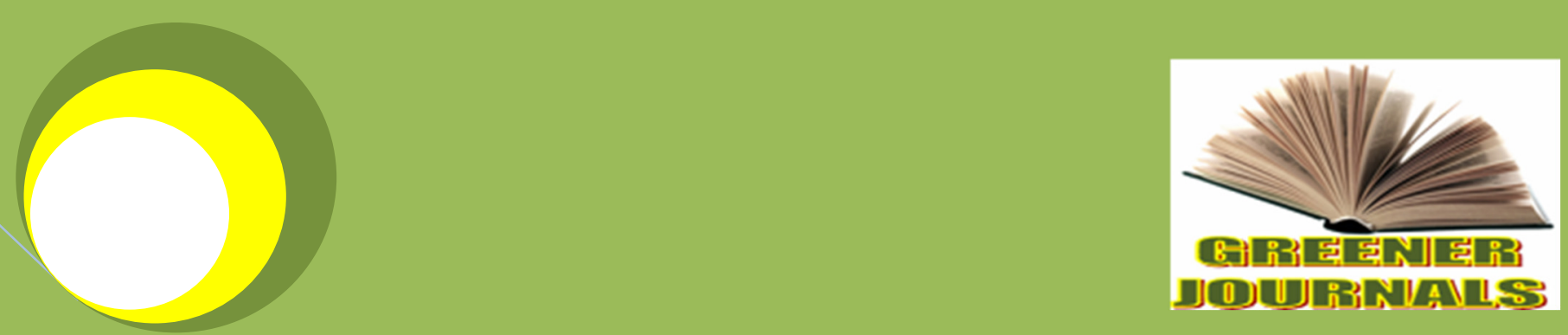

Greeney lournal of Educational Research

ISSN: 2276-7789 ICV: 6.05

Submitted: 12/08/2016

Accepted:17/08/2016

Published: 25/08/2015

DOI: http://doi.org/10.15580/GJER.2016.5.081216128

Influence of Student

Leaders Participation

in Management on

Institutional

Governance in Public

Universities, Kenya

By

Asesa-Aluoch Amondi Edna

Wanzare Ogolla Zachariah

Sika Ouma James 


\title{
Influence of Student Leaders Participation in Management on Institutional Governance in Public Universities, Kenya
}

\author{
*Ms. Asesa-Aluoch Amondi Edna, Dr. Wanzare Ogolla Zachariah \\ and Dr. Sika Ouma James
}

\author{
Maseno University, Department of Education Management and Foundations, P.O Box Private Bag Maseno \\ Kenya.
}

*Corresponding Author’s Email: ekohlerasesa@gmail.com

\begin{abstract}
This study investigated the extent of student participation management on institutional governance in public universities Kenya. The study was prompted by a recommendation by ministry of higher education in Kenya that students need to be involved more in management of their institutions, following a wave of unrest in Universities Kenya in 2014; with claims of uninvolvement in governance and research indicating unequal decision making opportunities in university. Data was collected by means of a questionnaire distributed among 194 student leaders' public universities. The findings revealed that universities involved students in governance of public university with a mean rating of 2.95 suggesting that there was shared governance in public Universities. However students' occasionally participated in decision making, thus, the study established a fairly low, significant positive correlations between the extent of student participation and institutional governance $[r=.220, n=190, p=.002]$. Hence, the null hypothesis was rejected; there was sufficient evidence to do so $(p<.05$ at Sig. Level $=.05)$. It was thus concluded that the frequently the students are involved in management, the higher the shared governance in public universities. Hence the study recommended that; occasional student participation in decision making needed to be improved especially in quality assurance and time table setting.
\end{abstract}

Keywords: Student Involvement/Participation, Institutional Governance, Shared Governance.

\section{INTRODUCTION}

Participation basically stated means to share in, take part, be or become actively involved. Ibijola (2010) noted that the history of students' participation in management of institutions dated back to the 19th century when Bell introduced the method of drilling older children who later taught the young ones. By so doing, the teachers' efforts became multiplied. The extent of student involvement in decision making is debatable with often conflicting viewpoints propagated by differing stakeholders depending on their background and world view. Basically there are three viewpoints that guide the extent of student involvement in decision making.

The first is that students must remain passive and receive instructions from parents and teachers (Sithole, 1998). This view will mean that policies must be designed by adults and students are to follow them to the letter. The second viewpoint suggests that students can participate but only to a certain degree (Squelch, 1999; Magadla, 2007). Aggrawal (2004) adds that while student representatives may not participate in matters relating to the conduct of examinations, evaluation of student performance, appointment of teachers and other secret matters, their participation should be ensured in all other academic and administrative decisions taken by these bodies. Though this view appears to support student participation in decision making, it however confines student involvement in decision making to specific areas of school life.

The notion is authoritarian and paternalistic, rather than democratic. It not only assumes that school students have a legitimate interest only in student-specific issues, but it also assumes that students have no right to decide for themselves the issues in which they want or do not want to be involved. For this reason, many commentators have suggested that opportunities for students' participation should go beyond specifically student-related issues and extend to wider aspects of school life, as well as to society beyond the school.

The third viewpoint suggests that students should fully participate in decision making (Magadla, 2007). Effective involvement, it has been said, would go beyond student comment on aspects of their lives which are seen 
as safe or without significant impact on the work of adults in the school, embedded at classroom level, at institutional level and at the interface between local, national and international communities (Fielding et al, 2003). In their support, Huddleston (2007) feels that students should be involved in all areas of school life adding that the range of activities that make up the work of a school can be categorized in a number of different ways, but, however it is categorized, one should expect students to have opportunities for involvement in each major area. Thus providing conflicting view points on extent student participation in decision making.

In a study conducted by Bergan (2005) on students' participation, he reported that higher education has been recognized as key to delivering the knowledge requirements for political development. Ibijola (2010) further noted that the rationale for students' participation is desirable, and identified them to include enhance students' commitment and performance and that, most of the problems leading to students' unrest could be resolved if students are allowed their rightful place in university governance. On this premise, committee system of management played very important roles in the decision making process in the management of universities in Nigeria. The importance of coordination in any organization, most especially in the university system cannot be over emphasized. It is in this light that the students' representatives should be seen as leaders in their own capacity, knowing fully that they represent the significant percentage of the university community. While making a case for rational of student participation and providing committee systems as a way of involving students in management, Ibijola (2010) failed to investigate the actual participation of students in this committee thus implying a relationship with organizational effectiveness based on perception of involvement.

The concept of student participation can be divided into formal and informal participation, which can be seen as examples of representative and direct democracy. Formal participation is collective, from the aspect that students exercise formal participation through representation on boards and committees. Informal participation is individual and concerns students' informal opportunities of influencing their own situation and education, e.g. through course evaluations and other forms of evaluation (Högskoleverket, 2000). Bergan, (2005), Ibijola (2010) and Högskoleverket (2000) have all justified student participation in decision making providing ways of doing so, with lbijola (2010) providing benefits of participation. However, they did not provide how far participation should go with no link to institutional governance even though providing indicators of shared governance.

On the other hand, Squelch (1999) and Magadla (2007) assert that students can get involved in their learning institutions "governance" but only to a limited extent. In his argument on the same issue, Aggarwal (2004), postulates that, while students may not be involved in affairs interconnected to the administration of examinations, appointment of lecturers and teachers, assessment of student performance and other institutional governance matters, their responsibility should spread out into all spheres affecting their welfare, both scholastic and managerial. Though this view appears to support student involvement in decision making, it however, confines student participation in decision making to particular areas of university life limiting student participation to committees only.

The findings of the previous studies and other literature reviewed however show that, university governance is a team work and that issue of institutional governance should not be seen as a prerogative of university management only. Hence in the management of higher institutions, committees play very important roles in the decision making process. This is because as democratic establishment, universities' decisions must reflect the opinion of a cross section of the staff and students if such decisions are to be acceptable to all. In one of his ten proposed principles towards keeping a university governance system healthy, Gerland (2004) said, people who will be affected by a major decision have the right to be heard. Students may resent those decisions to which they are not party to, and in an attempt by the university management to enforce such decisions, crisis situation may result thereby causing disruption in the academic calendar. This view point was supported by Nwaokolo (1998) and Longing (2002). The effective use of the committee system requires that the right persons should be used, while the choice of the right persons depends on their skills, ability and positions in the organization according to Ajayi \& Ayodele (2002). With clear grounds on the use of committee and the choice of right persons, Nwaokolo 1998, Longing (2002) and Ajayi \& Ayodele (2002) failed to investigate the actual involvement of the right persons in these committees not considering formal and or informal/ direct and or indirect forms of involvement.

As a governing body according to Ezekwem (2009), the Student Union Government provides the student body with activities and a forum to discuss school issues and plays a leading role with clubs and organizations within and outside the university system. Its major function also includes representing the entire student body and ensuring that their voices are heard and reflected in all levels of university decision making process. It seems the student union government makes the process of democratic representation and participation in the faculty and the university decision making burdens easier. By implication, the student union government and other associations on universities' campuses contribute positively to the effective governance of the university system. Gerland (2004) and Ezekwem (2009) while making a case for student participation in institutional governance and implying effective governance failed to measure actual involvement and or institutional governance. It is against the foregoing background information that this study sought to establish the extent student leaders' participation in management was measured 
by both direct and indirect participation and levels of decision making in committee and its influence on Institutional governance in public Universities in Kenya

\section{Problem statement}

The crucial role played by students in the management cannot be over stated. The provisions for participation have been guaranteed by legislation in individual university statutes of each of the public universities in Kenya having been drawn from the University Act 2012. Between the year 2010-2015, 32 cases of strikes were witnessed in public universities out of which $25(78.1 \%)$ were directly related to student affairs with complaints of non-involvement in decision making process and dissatisfaction with participation. Based on these considerations, the study sought to establish the extent of student participation in management and its influence in management.

\section{Research Objectives:}

i. Determine the extent of student participation in management

ii. Evaluate the influence of extent of student leaders' participation in management on Institutional Governance.

Research question: what is the extent of student participation in management?

Research hypothesis: There is no significant influence between the extent of student participation on Institutional governance

\section{Student participation in management on Institutional Governance}

Among the studies that have been conducted in Kenya, two have clearly shown that involving students in their learning is imperative. If university governance is shared, subsequently, students' feelings are more positive towards college goals and objectives (Obondo, 2000). Obondo further asserts that in the transformation of universities, the students should be involved. Student Association represents a significant untapped resource in university effort to confront the current crises. Student representatives have also been noted to have the capacity to diffuse potential conflicts. This, they can do through regular meetings with their members and administration, designing a mechanism for regular communication, thereby restraining their colleagues from unnecessary conflicts (Obondo, 2000).

Probably, the largest collection of studies on the topic is found in a Council of Europe Project on Education for Democratic Citizenship (CCHER Bureau 2000). The project was designed to examine the practices of universities in Europe and the US about the promotion of democratic values and practices. In this framework, studies were conducted in 15 European universities in different countries, and 15 colleges and universities in the United States. Interviews with students (and other stakeholders such as academics) were used to measure the extent of student participation in university governance. Students also reported on their satisfaction with institutional practices. According to the findings, the involvement of students in the governance of their universities was weak.

The representation of students in university committees is one of the main ways in which universities engage with students, listen to them, and involve them in their internal decision-making processes. Recent surveys indicate that the representation of students in decision making at institutional level is close to universal, though there is considerable variability between and within institutions so far as representation at lower organizational levels (e.g.; faculty, school/department, course) and across different issue-based governance domains (e.g.; teaching and learning, students' social issues, staffing) is concerned, Little,Locke, Scesa, \& Williams. (2009).

According to Luescher-Mamashela (2013), the extent of student representation on university committees dealing with teaching, learning and research may be understood with regard to the setting and level of governance (course, programme/department /school, faculty, university-wide academic policy), the nature of issues under consideration (e.g. student assessment, timetable setting, academic staffing, teacher awards, quality assurance) and, most importantly, the perceived expertise and seniority of the students affected by a decision (undergraduate, postgraduate). Provisions for student representation may involve consumerist commitments to giving students a formal mechanism to voice their preferences (amongst others, through surveys), thus providing input and feedback into the academic process. Academic staff's commitment to democratic and participatory pedagogies, involving notions of membership/partnership (and co-production) in a learning community, may also influence the extent to which students are involved in co-determining aspects of teaching and learning.

Contrasting the previous researches that were limited to areas of student participation, either in decision levels, formal or informal participation and only suggesting the areas where they should involve. The current study sought to determine the nature of student participation that is direct/ indirect representation to establish the extent of participation and students' involvement that goes beyond provisions to sit - in committee or provisions by law 
requirements being fulfilled by the university management. Although the studies reviewed looked at organisational effectiveness in terms of graduation rates and lack of disruptions in the university calendar, the current study focused on the institutional governance in entirety

\section{METHODOLOGY}

This was a descriptive and correlational study to establish the extent of student participation in management and its influence on institutional governance in public universities in Kenya. The population for this study consisted of 369 students' leaders and from seven public Universities that had attained university charter by 2013 in Kenya. The sample for this study was made up of 194 student leaders and stratified random technique was used to select the samples. The population was divided into stratas based on the offices they hold within the university.

The questionnaire was titled Students' leaders Questionnaire for data collection. The tool was adopted with modification from the Index of Professional Nursing Governance (IPNG) survey tool to obtain a measurement of shared governance. The face and content validity of the instrument were assessed by two experts in Test and Measurement, in the Faculty of Education, Maseno University, in order to ensure that the instrument adequately measured the intended content areas of the study. Their observations were used as a guide in reviewing the instrument before administering them to the subjects.

The reliability of the instrument was ascertained using the split-half method, i.e. the study utilized the scores from a single test to estimate the consistency of the test items. The split-half method reliability coefficient was corrected to full-length coefficient using the Spearman Brown prophecy formula. The resulting co-efficient was 0.89. Data obtained from the instrument were analyzed using descriptive method. SPSS version 20 was used to analyze the data. The return rate of questionnaire was $97 \%$ as 190 out of the 194 respondents filled in the questionnaire and returned.

\section{FINDINGS AND DISCUSSION}

The study sought to investigate the extent of student involvement in management and its influence on institutional governance. This objective was addressed by exploring the nature of students' involvement in management in the university and its influence in management on institutional governance.

\section{Extent of Students' Involvement in Management}

To investigate the extent of students' involvement in management, the student leaders' respondents were presented with a list of some of the university governance committees provided in university statutes and they were to indicate how they participate in decision making in these committees. The respondents were to indicate whether their participation was formal or informal in giving feedback, direct participation or participation by representation. Their responses were summarized as Figure 4.1.

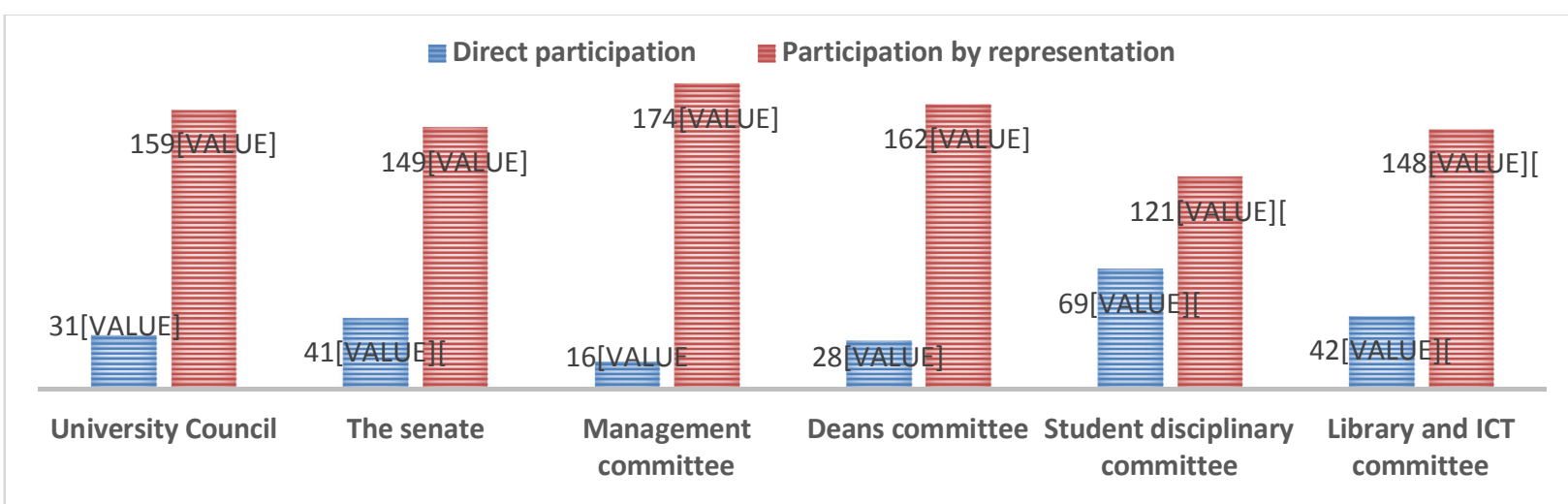

Figure 1: Nature of student involvement in management 
From Figure 4.1, it is clearly shown that the students are involved in university management mainly through representation in the university governance committee (the red bar graphs represent participation through representation, while the blue bar graphs represent direct participation). It emerged that direct participation of the students' leaders in many of the university governance committees was quite low in some committees but fair in others. For example, it was established that whereas $69(36.3 \%)$ of the student leaders who took part in the study confirmed their direct participation in student disciplinary committee, only $16(8.4 \%)$ of them directly participated in the university management committee with a significant majority of $174(91.6 \%)$ being involved in the university management through representation. Likewise, the findings of the study reveal that student are also more involved in the senate, and Library and ICT committees compared to others areas such as deans committee. This was reflected by the fact that more than a fifth of the student leaders who took part in the study indicated that they directly participate in the senate [41 (21.6\%)] and Library and ICT [42 (22.1\%)] committees, while on the other hand only 28 $(14.7 \%)$ of the student leaders were directly involved in the university deans' committee. $19.7 \%$ of the students believed that the nature of student participation was by direct participation while an over whelming 80.3 said participation is by representation.

The findings of the study concur with Lodge and Kaluti who postulate that Higher education settings provide a range of formal and informal mechanisms for student participation in governance. At the most fundamental and passive level, student feedback might be informally sought on specific issues (Lodge, 2005). These consultative mechanisms may take the form of student councils or committees. Students' voice may also be more systematically incorporated into governance forums. Thus, most universities mandate the formal membership of students on university-level committees (e.g. academic senate and disciplinary committees) to ensure adequate representation of constituencies (Kulati 2000).

Table 1: Student leaders Views on Extent of student Involvement in Management

\begin{tabular}{llllll}
\hline Item & SD & D & U & A & SA \\
\hline Students should participate in matters & 3 & 9 & 0 & 28 & 150 \\
affecting their welfare & $(1.6 \%)$ & $(4.7 \%)$ & $(0.0 \%)$ & $(14.7 \%)$ & $(78.9 \%)$ \\
Decisions should be left to experts & 104 & 39 & 14 & 13 & 20 \\
such as administrators & $(54.7 \%)$ & $(20.5 \%)$ & $(7.4 \%)$ & $(6.8 \%)$ & $(10.5 \%)$ \\
Students lack necessary expertise for & 97 & 44 & 5 & 23 & 21 \\
participating in management & $(51.1 \%)$ & $(23.2 \%)$ & $(2.6 \%)$ & $(12.1 \%)$ & $(11.1 \%)$ \\
\hline SA =Strongly Agree, A = Agree. UD = Undecided, SD = Strongly Disagree and D = Disagree. \\
Source: Study data (2016).
\end{tabular}

The study sought to explore the views of the students' leaders on the extent they thought they ought to be involved in management, in the university. It emerged that although an overwhelming majority of the students' leaders were in agreement that they should be fully involved in the management of the university, others held the perception that students should only be involved to some extent given that they still lack relevant and adequate expertise to make meaningful decisions. For examples, whereas nearly four out of every five [150 (78.9\%)] of the student respondents were in strong agreement that students should be involved to participate in all matters affecting their welfare, 33 $(17.3 \%)$ of them insisted that some decisions should be left to experts such as administrators. This point of view resonated with the one held by about a fifth [45 (23.2\%)] of the students leaders who held the general feeling that students lack necessary expertise for participating in university management especially in making decision that are key to the management of the university. On the contrary, about three quarters [143 (75.2\%)] of the student leaders who participated in the study repudiated the assertion that some decisions should be left to experts such as administrators. Similarly, $97(51.1 \%)$ of the students leaders who were sampled for the study rejected vehemently the claim that students lack necessary expertise to participate in university management; they argue that this point of reasoning adversely affect the spirit of shared governance. 
Table 2: Students Leaders Extent of participation in Level of Decision Making

\begin{tabular}{|c|c|c|c|c|c|c|c|c|}
\hline Items & $\mathrm{N}$ & AN & $\mathrm{O}$ & AET & $\mathrm{F}$ & $\mathrm{M}$ & SD & SE \\
\hline $\begin{array}{l}\text { University program (e.g B.Ed., } \\
\text { B.Sc., B.Med., B.A etc) }\end{array}$ & $\begin{array}{l}139 \\
(73.2 \%)\end{array}$ & $\begin{array}{l}27 \\
(14.2 \%)\end{array}$ & $\begin{array}{l}19 \\
(10.0 \%)\end{array}$ & $\begin{array}{l}2 \\
(1.1 \%)\end{array}$ & $\begin{array}{l}3 \\
(1.6 \%)\end{array}$ & 1.44 & 0.83 & 0.91 \\
\hline Student assessment & $\begin{array}{l}104 \\
(54.7 \%)\end{array}$ & $\begin{array}{l}28 \\
(14.7 \%)\end{array}$ & $\begin{array}{l}33 \\
(17.4 \%)\end{array}$ & $\begin{array}{l}6 \\
(3.2 \%)\end{array}$ & $\begin{array}{l}19 \\
(10.0 \%)\end{array}$ & 1.99 & 1.32 & 1.15 \\
\hline Time table setting & $\begin{array}{l}115 \\
(60.5 \%)\end{array}$ & $\begin{array}{l}15 \\
(7.9 \%)\end{array}$ & $\begin{array}{l}41 \\
(21.6 \%)\end{array}$ & $\begin{array}{l}16 \\
(8.4 \%)\end{array}$ & $\begin{array}{l}3 \\
(1.6 \%)\end{array}$ & 1.83 & 1.12 & 1.06 \\
\hline Semester dates & $\begin{array}{l}110 \\
(57.9 \%)\end{array}$ & $\begin{array}{l}30 \\
(15.8 \%)\end{array}$ & $\begin{array}{l}32 \\
(16.8 \%)\end{array}$ & $\begin{array}{l}14 \\
(7.4 \%)\end{array}$ & $\begin{array}{l}4 \\
(2.1 \%)\end{array}$ & 1.80 & 1.09 & 1.04 \\
\hline Quality assurance & $\begin{array}{l}118 \\
(62.1 \%)\end{array}$ & $\begin{array}{l}22 \\
(11.6 \%)\end{array}$ & $\begin{array}{l}39 \\
(20.5 \%)\end{array}$ & $\begin{array}{l}5 \\
(2.6 \%)\end{array}$ & $\begin{array}{l}6 \\
(3.2 \%)\end{array}$ & 1.73 & 1.07 & 1.03 \\
\hline Campus security & $\begin{array}{l}72 \\
(37.9 \%)\end{array}$ & $\begin{array}{l}19 \\
(10.0 \%)\end{array}$ & $\begin{array}{l}44 \\
(23.2 \%)\end{array}$ & $\begin{array}{l}26 \\
(13.7 \%)\end{array}$ & $\begin{array}{l}29 \\
(15.3 \%)\end{array}$ & 2.58 & 1.48 & 1.21 \\
\hline Student disciplinary & $\begin{array}{l}66 \\
(34.7 \%)\end{array}$ & $\begin{array}{l}37 \\
(19.5 \%)\end{array}$ & $\begin{array}{l}33 \\
(17.4 \%)\end{array}$ & $\begin{array}{l}16 \\
(8.4 \%)\end{array}$ & $\begin{array}{l}38 \\
(20.0 \%)\end{array}$ & 2.59 & 1.51 & 1.23 \\
\hline Students accommodation & $\begin{array}{l}68 \\
(35.8 \%)\end{array}$ & $\begin{array}{l}20 \\
(10.5 \%)\end{array}$ & $\begin{array}{l}41 \\
(21.6 \%)\end{array}$ & $\begin{array}{l}26 \\
(13.7 \%)\end{array}$ & $\begin{array}{l}35 \\
(18.4 \%)\end{array}$ & 2.68 & 1.52 & 1.23 \\
\hline Students sports & $\begin{array}{l}35 \\
(18.4 \%)\end{array}$ & $\begin{array}{l}40 \\
(21.1 \%)\end{array}$ & $\begin{array}{l}61 \\
(32.1 \%)\end{array}$ & $\begin{array}{l}17 \\
(8.9 \%)\end{array}$ & $\begin{array}{l}37 \\
(19.5 \%)\end{array}$ & 2.90 & 1.34 & 1.16 \\
\hline Students elections & $18(9.5 \%)$ & $\begin{array}{l}33 \\
(17.4 \%)\end{array}$ & $\begin{array}{l}50 \\
(26.3 \%)\end{array}$ & $\begin{array}{l}37 \\
(19.5 \%)\end{array}$ & $\begin{array}{l}52 \\
(27.4 \%)\end{array}$ & 3.38 & 1.30 & 1.14 \\
\hline peer counseling & $\begin{array}{l}30 \\
(15.8 \%)\end{array}$ & $\begin{array}{l}29 \\
(15.3 \%)\end{array}$ & $\begin{array}{l}59 \\
(31.1 \%)\end{array}$ & $\begin{array}{l}44 \\
(23.2 \%)\end{array}$ & $\begin{array}{l}28 \\
(14.7 \%)\end{array}$ & 3.06 & 1.26 & 1.12 \\
\hline $\begin{array}{l}\text { Offering Students services eg. } \\
\text { canteens, bookshops etc }\end{array}$ & $\begin{array}{l}28 \\
(14.7 \%)\end{array}$ & $\begin{array}{l}50 \\
(26.3 \%)\end{array}$ & $\begin{array}{l}58 \\
(30.5 \%)\end{array}$ & $\begin{array}{l}26 \\
(13.7 \%)\end{array}$ & $\begin{array}{l}28 \\
(14.7 \%)\end{array}$ & 2.87 & 1.25 & 1.12 \\
\hline $\begin{array}{l}\text { Provision of financial } \\
\text { assistance to needy students }\end{array}$ & $\begin{array}{l}49 \\
(25.8 \%) \\
\end{array}$ & $\begin{array}{l}22 \\
(11.6 \%) \\
\end{array}$ & $\begin{array}{l}72 \\
(37.9 \%) \\
\end{array}$ & $\begin{array}{l}26 \\
(13.7 \%) \\
\end{array}$ & $\begin{array}{l}21 \\
(11.1 \%) \\
\end{array}$ & 2.73 & 1.28 & 1.13 \\
\hline
\end{tabular}

Key: $\mathbf{N}=$ Never, $\mathbf{A N}=$ Almost Never, $\mathbf{O}=$ Occasionally, $\mathbf{A E T}=A$ lmost Every Time and $\mathbf{F}=$ Frequently;

$\mathbf{M}=$ Mean, $\mathbf{S D}=$ Standard deviation and $\mathbf{S E}=$ Standard error

Source: Study data (2016)

On the areas and levels of decision making in university governance, the findings of the study show that students get involved differently in diverse areas of the university management. For instance, it emerged that students leaders are more involved [almost every time: 37 (19.5\%); frequently: 52 (27.4\%)] involved in making decisions related to students elections. This fact had the highest mean $(m=3.38, S D=1.30$ and $S E=1.14)$ shown by the frequency of responses received from the student leaders. However, more than a quarter [50 (26.3\%)] of the student leaders alluded that they only occasionally are involved in such decisions related to students election and a further 51 $(26.9 \%)$ of them said that their opinion on student elections is rarely sought or they are always totally never involved in such decisions.

It emerged that decision on peer counseling and offering student services e.g. canteen also received considerably higher involvement of the students' leadership, with a mean of 3.06, standard deviation of 1.26 and standard error of 1.12. It was established that students are mostly [almost every time: 44 (23.2\%); frequently: 28 $(14.7 \%)]$ involved in making decisions related to peer counseling. Likewise, the findings of the study reveal that nearly three out of every ten [54 (28.4\%)] of the student leaders who took part in the study confirmed that they are always involved in making decisions regarding services offered by the students such as running canteen, book stores and internet cafes, tuck shops and restaurants, among others. On the contrary, $30(15.8 \%)$ and $28(14.7 \%)$ of the student leaders respondents negated the claim that they are always involved in decisions related to peer counselling and services offered by the students, respectively. They asserted that their involvement is insignificant as regards decision making. This concurs with Luescher, 2005 who opined that, in most cases, the students supplement the services that are offered by the university. These include services such as assistance with academic and 
administrative problems, peer counseling, the provision of financial aid to needy colleagues, provide study facilities and services, run businesses such as bookstores, internet cafes, tuck shops and restaurants (Luescher, 2005). In this case, they have to work together with the senior managers such as the dean of students or the director of student affairs (Luescher, 2005). Student governance is about representing and serving the student body.

The results of the study confirm that although university management try to embrace the idea of shared decision making by sharing responsibilities and having joint effort in decision making by all major stake holders including students through their leaders, this has not been fully achieved, as reflected by the findings of this study. The university management still dominates many areas with quite a minimal level of students' involvement. For instance, at the levels of university programs (e.g. B.Ed., B.Sc., B.Med., B.A etc.), student assessments, quality assurance and semester dates, university management enjoy overwhelming authority to make decisions. Only 5 $(2.7 \%)$ of the students leaders said they are involved in making decisions concerning university programs, 25 $(13.2 \%)$ of them participate in student assessments committees, $11(5.8 \%)$ of them are involved in quality assurance decisions and only $18(9.5 \%)$ of the student leaders observed that they are often involved in making decisions on semester dates. Similarly, contrary to the generally held opinion that university students, through their representatives, are always involved in timetabling committees, the findings of the study reveal that significant majority of $115(60.5 \%)$ of the student leaders who took part in this study said they are never involved in time table setting. In fact, of the few [41 (21.6\%)] who agree that they get involved in the time table setting process said they are only involved occasionally. Those who alluded that they are always involved in timetabling committee formed a near negligible proportion [3 (1.6\%)] of the student leaders who took part in the study.

On the contrary, the findings of the study confirm that there is fair representation of student leaders in some committees in the university. For example, in the committees of campus security, student discipline, student accommodation and students' sports, the students are well involved in decision making. It was discovered that 55 $(29.0 \%)$ of the student leaders are always involved in decisions related to campus security, $67(34.3 \%)$ are often involved in student accommodation committees and $54(28.4 \%)$ others said they always participate in making decisions related to student sports. In addition, in the provision of financial assistance to needy students, the findings of the study show that although $49(25.8 \%)$ of the students said they are never involved in making decision in this area, a significant proportion [72 (37.9\%)] agreed they are occasionally involved, but about one out of every four, 47 (24.8\%), student leaders who took part in the study asserted that they are always involved in decision making related to provision of financial assistance to needy students.

These findings concurs with student Love \& Miller, (2003) who opined that; leaders are empowered to take control of matters affecting the students such as in the disciplinary matters. The student voices are easily heard at this level compared to other levels, they can call for an opportunity to contribute towards the academic programs in the university and the restructuring of the administrative system. Student leaders have typically held control over many aspects of student life, such as fee distribution, but have not been given equal status with their faculty members in decision making in areas such as course scheduling or other curricular matters. However as much as they did not give the exact percentage of the extent of participation, they agreed that their voices are easily heard at this levels compared to others

The findings also concur with Adesanoye (2000) posits, "students' union representatives are allowed to serve as members on some of these universities' committees". At the University of Ado-Ekiti, for example, the regulation governing student council allows for students representatives to serve as members of the following university committees; the students' disciplinary committee; where students who breached their matriculation oaths are tried and punished accordingly, the security committee, the students' electoral committee, ceremony Committee and sports committee among others in Nigeria.

\section{The influence of extent of students' involvement in management on institutional governance}

To address this objective, the null hypothesis that, "there is no relationship between the extent of students' involvement in management and institutional governance" was tested. The researcher investigated whether there was any significant relationship between the extent of students' involvement in management and institutional governance in university. To establish the relationship between the variables, a bivariate Pearson Product-Moment Correlation Coefficient was computed. The overall scores of the extent of student involvement in management, which was computed by getting the mean responses frequencies from the Likert-scaled items, was the independent variable, while the scores of student involvement in shared governance was used as the dependent variable. Preliminary analyses were performed to ensure no violation of the assumptions of normality. The correlation coefficient was as shown in Table 4.9. 
Table 3: Correlation between Extent of Student Involvement in Management and Institutional Governance

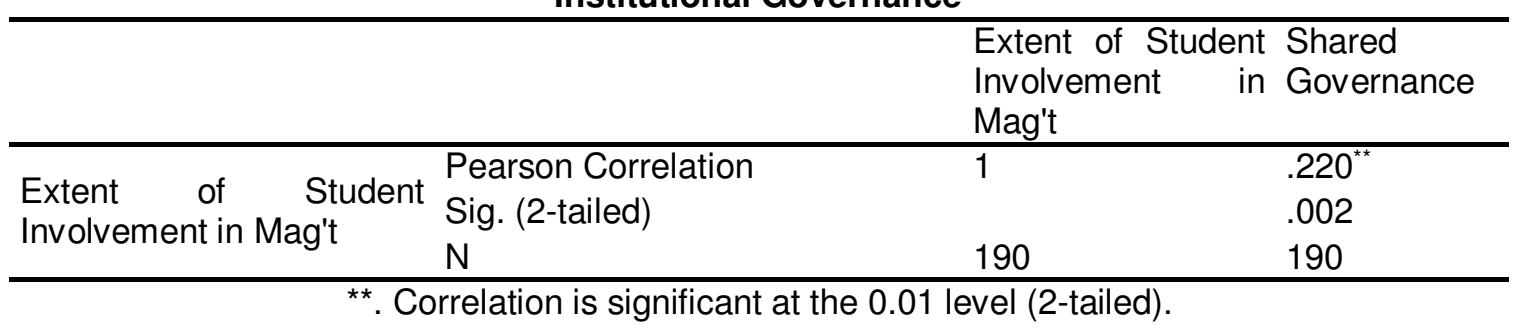

The findings of the study show that there was a fairly low, significant positive correlations between the two variables $[r=.220, n=190, p=.002]$, as indicated in Table 4.19. Hence the null hypothesis was rejected; there was sufficient evidence to do so $(p<.05$ at Sig. Level $=.05)$.

However, given that the extent of student involvement in management was measured in two facets; student participation and levels of decision making, a linear regression analysis was further used to investigate their individual relationship with the dependent variable. The regression was conducted to investigate how well the set of the independent variable was able to predict the level of shared governance in the university governance. This was done using the standard multiple regression analysis, where the two independent variables were included in the model.

Table 4.10: Model Summary

\begin{tabular}{|c|c|c|c|c|c|c|c|c|c|}
\hline Model & $\bar{R}$ & R Square & Adjusted & Std. Error & Change S & atistics & & & \\
\hline & & & R Square & $\begin{array}{l}\text { of the } \\
\text { Estimate }\end{array}$ & $\begin{array}{l}\text { R Square } \\
\text { Change }\end{array}$ & $\begin{array}{l}\mathrm{F} \\
\text { Change }\end{array}$ & df1 & df2 & $\begin{array}{l}\text { Sig. F } \\
\text { Change }\end{array}$ \\
\hline 1 & $237^{a}$ & 056 & .046 & .94877 & .056 & 5.583 & 2 & 187 & .004 \\
\hline
\end{tabular}

a. Predictors: (Constant), Levels of decision making, Student participation

In the Model Summary (Table 4.10), the value of $R$ Square (.056) indicates how much of the variance in the dependent variable (institutional governance) was explained by the two variables: levels of decision making and student participation. This value expressed as a percentage means that the model explains 5.6 percentage of the variance in scores of shared governance. To assess the statistical significance of the result, the ANOVA output shown in Table 4.11 was used to tests the null hypothesis that multiple $\mathrm{R}$ in the population equals 0 .

Table 4.11: ANOVA Output

\begin{tabular}{lllllll}
\hline Model & & Sum of Squares & Df & Mean Square & F & Sig. \\
\hline \multirow{4}{*}{1} & Regression & 10.051 & 2 & 5.026 & 5.583 & $.004^{\mathrm{b}}$ \\
& Residual & 168.329 & 187 & .900 & & \\
& Total & 178.381 & 189 & & & \\
\hline
\end{tabular}

a. Dependent Variable: Institutional Governance

b. Predictors: (Constant), Levels of decision making, Student participation

From the output, it was clear that model reached statistical significance $[F(2,189)=5.58$, Sig $=.004]$, implying that the model was adequate enough to explain the variance in the scores of shared governance.

\section{Evaluating contribution of each of the two independent variables}

From the output box of coefficients, a look at the Beta values under standardized coefficients reveals that each aspect of extent of student involvement in management contributes differently to the model, as shown in Table 4.12. 
Table 4.12: Coefficients Output

\begin{tabular}{|c|c|c|c|c|c|c|c|c|}
\hline \multirow[t]{2}{*}{ Model } & \multicolumn{2}{|c|}{$\begin{array}{l}\text { Unstandardized } \\
\text { Coefficients }\end{array}$} & \multirow{2}{*}{$\begin{array}{l}\text { Standardized } \\
\text { Coefficients } \\
\text { Beta }\end{array}$} & \multirow[t]{2}{*}{$\mathrm{t}$} & \multirow[t]{2}{*}{ Sig. } & \multicolumn{3}{|c|}{ Correlations } \\
\hline & $\mathrm{B}$ & Std. Error & & & & Zero-order & Partial & Part \\
\hline (Constant) & 1.889 & .320 & & 5.897 & .000 & & & \\
\hline${ }_{1}$ Student participation & .097 & .087 & .079 & 1.114 & .267 & .093 & .081 & .079 \\
\hline $\begin{array}{l}\text { Levels of decision } \\
\text { making }\end{array}$ & .251 & .082 & .219 & 3.074 & .002 & .224 & .219 & .218 \\
\hline
\end{tabular}

a. Dependent Variable: Institutional Governance

To compare the different variables, a standardized coefficient (beta values) was used because the values for each of the different variables were converted to the same scale so that they could be easily compared. The larger Beta coefficient was .219, which was for levels of decision making, implied that this variable made a stronger unique contribution in explaining the variation of the dependent variable, when the variance explained by the other variable in the model was controlled for. The Beta value for the variable of student participation was the least (beta=.079), indicating that it made the least contribution to the model. It was therefore not surprising to discover that it did not reach statistical significance $(p=.267)$, meaning its contribution to the variability of scores in the shared governance scale was negligible. This was again reflected in the column of the part correlation coefficients, which when squared gives an indication of the contribution of that variable to the total $R$ squared. In other words, it reveals how much of the total variance in the dependent variable is uniquely explained by that variable and how much $\mathrm{R}$ squared would drop if it wasn't included in the model. For example, the variable student participation had a part correlation coefficient of .079 , when squared gave only a mere .0062, indicating that it uniquely explains only .62 per cent (negligible!) of the variance in Institutional governance scores. On the contrary, for the variable- level of decision making, the value was .218 , which when squared gave .0475 , indicating a unique contribution of 4.8 per cent to the explanation of variance in shared governance scores. It was noted that the total R squared value for the model (.237 or 23.7 per cent explained variance) in the model in table 4.10 , did not equal to two squared part correlation values added up i.e. $(.0062+.0475=.05374)$. This was because the part correlation values represented only the unique contribution of each aspect of extent of student involvement in management, with any overlap or shared variance removed. The total $\mathrm{R}$ squared value, however, included the unique variance explained by each variable and also that which is shared.

The findings of the study concurs with Amakolafe and Ibijola (2011) study, which revealed a moderate level of students' participation in university management, and a corresponding moderate level of organizational effectiveness, implying that students' participation in university management is on the average with an average level on organizational effectiveness. This is an indication that in spite of the numeric strength of the students as an important stakeholder in the university community, their level of participation in management is just moderate. The study also concur with Ibijola (2014) whose study further revealed a significant difference among students' participation in university management in AAUA, EKSU and NSUK. Findings revealed that the mean difference between AAUA and EKSU, EKSU and NSUK is statistically significant at 0.05 levels. However, there existed no statistical significant difference in the organizational effectiveness of AAUA and NSUK. However, there is significant difference on organizational effectiveness in the management of AAUA, EKSU and NSUK. It implies that the three universities differ in their level of organizational effectiveness. This further establishes the significant relationship between students' participation in management and university management effectiveness. The significant relationship between student's participation in management and institutional governance in the public universities in Kenya established in this study agrees with Akomolafe and Ibijola (2012), who submitted that there exist a significant relationship between students' participation in university governance and organizational effectiveness. This therefore, implies that the higher the extent of students' participation in university management is, the higher the degree of shared governance will be.

\section{CONCLUSION}

The study identified that the students' are involved in management almost all the time. The significant relationship established between the extent of student participation and institutional governance was an indication that, most of the problems leading to students' unrest could be resolved if students are more involved in university governance. This implies that institutional governance could be shared with frequent involvement of students' in management of universities. 


\section{RECOMMENDATIONS}

In view of the significant relationship established between institutional governance, and the extent of students' participation in management of public universities, the extent of students' participation in management could be increased by allowing representatives of the students' union council to involve in decision making especially concerning semester dates, time-table setting, quality assurance and students assessments. Management is encouraged to ensure that students' contribution at meetings count in decision making process. By so doing, university management will enjoy stability and facilitate shared governance.

\section{REFERENCES}

AAUP Collection (MUM00513) owned by the University of Mississippi, Archives and Special Collections Adegun OA (2003). Sociology of Education. Printed and Published by Petoa Educational Publishers, Ekiti State.

Adesanoye, A. P. (2000). A study of Students participation in School Management. A case study of some Secondary Schools in Ikale Local Government Area of Ondo State; An unpublished M.Ed Thesis. O.A.U. Ile- Ife.

Aggarwal, J.C. (2007). Development and planning of modern education, (8th Ed). New Delhi: Vikas publishing house. Ajayi IA, Ayodele JB (2002). Fundamentals of Educational Management. Greenline Publishers, Ado-Ekiti, Nigeria.

Akindutire IO (2004). Administration of Higher Education. Sunray Press, Lagos, Nigeria.

Akomolafe C. O., (2002). Principals' behaviour and staff development in Ekiti State Secondary Schools. Unpublished Ph.D. thesis.

Akomolafe, C. O., \& Ibijola, E. Y. (2012). Rationale for students' participation in university governance in Ekiti and Ondo states, Nigeria. International Journal of Education Administration and Policy Studies, 4(1), 14-18.

Akomolafe, C.O., \& Ibijola, E.Y (2011). Students' participation in university governance and organizational effectiveness in Ekiti and Ondo states, Nigeria. American Journal of Social and Management Sciences, 2(2): 231-236.

Bergan, S. (2005). Student participation in higher education governance. Retrieved from; http://www.int/t/dg4/highereducation/resource/heseries_en.asp

Burgan, M. (2006). What ever happened to the faculty? Drift and decision in higher education. Baltimore, MD, The John Hopkins University Press.

CC-HER Bureau (2000). Universities as Sites of Citizenship and Civic Responsibility, Document DGIV/EDU/HE 36. Strasbourg: Council of Europe. Committees, Studies in Higher Education, 34:1, 69-84, DOI: $10.1080 / 03075070802602000$

Ezekwem CC (2009). Students Unionism and University Administration in Nigeria Retrieved from http://u08cgpublisher.com/proposals/368/index.html. on 24/03/15.

Gerland JC (2004). 2004 State of the University address. Autum Semester 2004 and the kick-off of miami universitys 196th academic year. Retrieved from http://en.wikipedia.org/wiki/gerland/ university address, On 20/09/2013.

Huddleston, T. (2007). From student voice to shared responsibility: effective practice in democratic school governance in European schools: London: Citizenship Foundation.

Ibijola, E. Y. (2010). Students' Participation in University Governance and Organizational Effectiveness in Ekiti and Ondo States Nigeria. M.Ed. Thesis Submitted to the Department of Educational Foundations and Management, Ekiti State University, Ado-Ekiti.

Ijomah, B. I. C. (2001). Strutural dacay and indiscipline in Nigerian institutions; the fault of government. Proceedings of the 12th General Assembly of SSAN 2001 (pp. 182-189). Greenline Publishers.

Kulati, T. (2000). Governance, leadership and institutional change in South African higher managed care. Psychiatric Services 52: 461-64

Lodge, C. (2005). From hearing voices to engaging in dialogue: Problematising student participation in school improvement. Journal of Educational Change 6: 125-46.

Longing TC (2002). Institutional governance: A call for collaborative decision making in America higher education. Baston MA Anker Publishing Co.

Love, R., \& Miller, M. (2003). Increasing Student Participation in Self governance: A comparison of graduate and Undergraduates Perception. College Student Journal. Vol. 37. p. 532-544

Luescher, T. M. 2005a. Student Governance in Africa. Paper presented at the Seminar on Improving Governance and Student Leadership, organized by the Centre for Higher Education Transformation at the University of Stellenbosch, South Africa, 01 April. [Online]. Available at: http://www.chet.org.za [9 November 2005].SS

Luescher-Mamashela, T.M. (2013). The African university and democratic citizenship: Hothouse or training ground? Report on student surveys conducted at the universities of Nairobi, Dar es Salaam and Cape Town;Cape Town: Centre for Higher Education Transformation. Management, 11, 167-182. 
Magadla, M. (2007). The role of the learner in school governing body: Med. Thesis; University of Kwa-Zulu Natal, South Africa.

Menon. M. E. (2005). Students view regarding their participation in University Governance: Implication for distributed leadership in Higher education. Tertiary education and management. Vol. 11. p. 167-182.

Nwaokolo, P. O. (1998). Democratization of the education System in Nigeria. A paper presented at the Second National Conference on democratization of educational System in Nigeria, held at Federal College of Education, Obudu, Cross River State 22nd - 25th March, 1998.

Obondo, A.T. (2000). Politics of Participatory Decision-Making: The Case of Kenyatta University and the University of Nairobi, French Institute for Research in Africa "Les Cahiers" Review no 19, November-December.

Squelch, J. (1999) Decentralized School Governance in South African Schools in Magadla, M. (2007) The Role of the Learner in the School Governing Body: Perceptions and Experiences of Principals, Educators, Parents and Learners. Unpublished Med Thesis: University of Kwazulu- Natal.

Cite this Article: Asesa-Aluoch AE, Wanzare OZ and Sika OJ (2016). Influence of Student Leaders Participation in Management on Institutional Governance in Public Universities, Kenya. Greener Journal of Educational Research, 6(5): 202-212, http://doi.org/10.15580/GJER.2016.5.081216128 